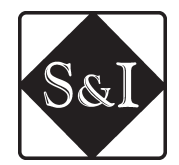

RESEARCH AND ENGINEERING

INNOVATIVE PROJECTS

DF THE NATIONAL ACADEMY

OF SCIENCES OF UKRAINE

https://doi.org/10.15407/scine16.05.071

SOKOLENKO, L.V. ', SOKOLENKO, T.M.', YAGUPOLSKII, YU.L. ', KALCHENKO, V.I. ', VERESENKO, YU.V. ${ }^{2}$, NENIA, O.V. ${ }^{2}$, KUCHYNSKYI, YU.D. ${ }^{2}$, SMERNYTSKYI, D.V. ${ }^{2}$, SKOROBAGATKO, O.V. ${ }^{2}$, SKOROBAGATKO, M.A. ${ }^{3}$, and KOLOMIIETS, S.I. ${ }^{3}$

'Institute of Organic Chemistry, the NAS of Ukraine, 5, Murmanska St., Kyiv, 02660, Ukraine, +380 $445590349,+380445732643$, ioch@ioch.kiev.ua

${ }^{2}$ State Research Institute of the MIA of Ukraine, $4 \mathrm{a}, \mathrm{Y}$. Gutsalo Lane, Kyiv, 01011, Ukraine, +380 44280 0184, dndi@mvs.gov.ua

${ }^{3} \mathrm{~K} 9$ Unit of the National Police of Ukraine, 10, Academica Bogomolca St., Kyiv, 01601, Ukraine,

+38044254 7735, kinologs1@police.gov.ua

\title{
NARCOTIC DRUG SMELL MIMICS FOR DOG TRAINING AT CYNOLOGICAL DEPARTMENTS: COMPOSITION, PRINCIPLE OF ACTION AND LEGAL FRAMEWORK OF THEIR USE
}

Introduction. Involvement of cynological departments to narcotics identification is widely used due to high sensitivity of canine olfaction.

Problem Statement. Currently, cynological departments of the MIA of Ukraine can use the samples of original narcotics in detector dogs learning and training for the purpose of developing or maintaining of the corresponding skill. However, narcotics are the substances under control; therefore, special normative procedures for their obtaining, usage, storage, and utilization exist. This order greatly complicates dogs training.

The use of original narcotics is reasonable in special cynological schools during basic learning of detector dogs. Further training in departments is oriented to maintain skills and, as a rule, is carried out using pseudo narcotic scents, which does not contain original narcotics and does not possess narcotic activity. Majority of such pseudo narcotic scents is of foreign production and are expensive. This fact does not allow to provide with training aids all the cynological departments of the MIA of Ukraine. Moreover, these pseudo narcotic scents are of limited range.

Purpose. The purpose of this research is to develop domestic pseudo narcotic scents with extended range, which would not possess narcotic activity, but have similar odor properties like original narcotics and are cheaper in comparison to foreign counterparts.

Citation: Sokolenko, L.V., Sokolenko, T.M., Yagupolskii, Yu.L., Kalchenko, V.I., Veresenko, Yu.V., Nenia, O.V., Kuchynskyi, Yu.D., Smernytskyi, D.V., Skorobagatko, O.V., Skorobagatko, M.A., and Kolomiiets, S.I. Narcotic Drug Smell Mimics for Dog Training at Cynological Departments: Composition, Principle of Action and Legal Framework of Their Use. Sci. innov. 2020. V. 16, no. 5. P. 71-78. https://doi.org/10.15407/scine16.05.071 
Materials and Methods. Pseudo narcotic scents of cocaine, heroin, marijuana, methamphetamine, opium, and poppy straw were developed. These training aids consist of inert carrying agent and volatile organic impurities from narcotics. These training aids were tested with involvement of 12 detector dogs of the cynological departments of the National Policy of Ukraine and State border service of Ukraine.

Results. Pseudo narcotic canine training aids for cocaine, heroin, marijuana, methamphetamine, opium, and poppy straw were created and tested with detector dogs. It was shown that odorological profile of pseudo scents agreed with original narcotics.

Conclusions. Pseudo narcotic scents which are perspective for introduction into production and further usage as canine training aids in cynological departments have been established.

Keywords : pseudo narcotic scents, cocaine, heroin, marijuana, methamphetamine, opium, poppy straw.

At the present stage of their development, canine units of the Ministry of Internal Affairs of Ukraine solve specific problems in the fight against crime, since a specially trained service dog can be considered a very valuable supersensitive device, indispensable for fulfilling official tasks related to detecting and identifying criminals, tools and objects of crime. One of the common objects of crimes committed in our country, because of its geographical location, are objects of the drug industry, including narcotic drugs (ND) and psychotropic substances.

The availability and quality of training samples, including the samples of authentic drugs are very important for special canine training that provides the acquisition and memorization of the necessary skills of searching, detecting, identifying, and signaling about the detected narcotic drugs, in addition to care, maintenance, well-designed and prepared facilities close to the real situation.

The special training of service dogs in the canine units of the Ministry of Internal Affairs of Ukraine is governed by many factors. For example, pursuant to the Regulations for the Organization of Canine Units of the National Police of Ukraine [1], for training service dogs, in police units and departments, the canine services are allowed to use odorous samples of authentic drugs to develop or to maintain appropriate skills aiming at further search for such means and substances while fulfilling relevant official tasks. At the same time, the use of authentic drugs is strictly accountable, as they are included in Tables I, II, and III of the list of drugs, psychotropic sub- stances, and precursors, approved by the Cabinet of Ministers of Ukraine no. 770 dated May 6, 2000 [2], which requires compliance with the special procedure for using narcotic drugs and psychotropic substances while training service dogs, for which there are special protocols for requesting, receiving, using, returning, storing, and destroying narcotic drugs and psychotropic substances. This paperwork takes time and essentially complicates the training of service dogs. In addition, regular inhalation of narcotic drugs is harmful to the dog health. For example, regular use of cocaine while training, exercising, and performing duties weakens the dog's sense of smell by reducing vascular permeability and subsequent infarction of the nasal nerve endings [3]. Also, it should be noted that even if narcotic drugs are produced by the same technology, impurities in different batches may vary because illegal laboratories cannot accurately reproduce the reaction conditions or get the absolute purity of product because of the lack of specific equipment and skills [4]. In addition, often "street" drugs are "diluted" with inert substances that do not have narcotic activity, but have a specific odor (for example, methamphetamine is added with dimethyl sulfone [4]). Therefore, a dog trained for the smell of a "diluted" narcotic drug can search for the impurity instead of the drug itself, which makes it impossible to search for the same narcotic drug of another origin.

As a result, today the use of authentic highquality drugs for training activities remains the prerogative of canine schools, where the service dog receives basic training. Further training that 
aims at maintaining the skills of searching, identifying, and signaling of detected drugs is carried out directly in the practical units with the use of foreign-made pseudo narcotic scents that have no narcotic activity.

The most common industrial pseudo narcotic scents are manufactured by Sigma (USA): Sigma Pseudo Narcotic Scent Heroin, Sigma Pseudo Narcotic Scent Cocaine, Sigma Pseudo Narcotic Scent Marijuana and ScentLogix (USA): K9 Scent Detection Training Aids. However, the practice has shown that using such products has several significant disadvantages, in particular: high cost; often cases of the necessity of special storage conditions; the absence of a complete set of odorological components that are present in authentic drugs; some pseudo narcotic scents, in particular those manufactured by Sigma, contain silica gel that if regularly inhaled may cause silicosis into the lungs of a dog and a dog trainer [5].

Thus, the above reasons have necessitated the creation of domestic pseudo narcotic scents that have a lower cost in order to fully meet the needs of the canine units of the Ministry of Internal Affairs of Ukraine and to expand the range of currently available mimics that do not require special storage and handling conditions.

\section{TESTING THE DESIGNED FORMULATIONS ON SERVICE DOGS}

The recipes have been tested at the Canine Center of the Central Office of the National Police in Kyiv, the Canine Center of the Central Office of the National Police in Kyiv Oblast and the canine group of BCP Kyiv of the State Border Guard Service of Ukraine with the involvement of service dogs trained for narcotic drug smell with the use of foreign-made pseudo narcotic scents ScentLogix or authentic drugs. Service dogs of the following breeds are involved (the number corresponds to the ordinal number of the dog): Eastern European Shepherd 1, 2; Belgian Shepherd Malinois 3; German Shepherd 4, 5; Labrador 6, 7, 8; Cocker Spaniel 9; Russian Spaniel 10; English Spaniel 11; and Fox Terrier 12.
The tests are made in accordance with the Program and Method Statement for testing samples of pseudo narcotic scents as approved by the State Research Institute of the Ministry of Internal Affairs of Ukraine on 26.07.2017 and by the Canine Department of the National Police of Ukraine on 27.07.2017, in normal climatic conditions according to GOST 15150-69:

- ambient temperature: $20 \pm 10{ }^{\circ} \mathrm{C}$;

- relative humidity: $45-80 \%$;

- atmospheric pressure: $84.0-106.7 \mathrm{kPa}$ or 630-800 mm Hg.

The tests were made at different dog training centers, at different times, with the use of improved or modified formulations, so a dog that was involved in trial of a certain scent may not get to the next test of improved formulations.

During each test, the products are tried by at least two service dogs. Products are searched in one stage alternately by each service dog present at the tests. At least, 5 wooden boxes are placed in a row for searching the products.

In arbitrary order, a special container is placed inside one of the boxes. Inside the container, there is a bag made of dense fabric. Before the trial, $50 \mathrm{~g}$ product is placed into the bag, in order to ensure the unimpeded release of the product smell. These actions are done in the absence of inspector and service dog, who are involved in the trial, in order to prevent visual detection of the box containing the product. When the sample is hidden, a dog inspector with a service dog is invited to the site. Upon the command of the dog inspector, the service dog searches for the hidden product by sniffing each box, passing along them up to 3 times. Based on the test results, the degree of interest of the service dog while searching for the product is established with the use of the following gradations: "no reaction", "interest", "clear detection".

The test results are considered positive, and each individual product is recorded as such that has passed trial, if while searching it, at least, two dogs show "clear detection".

The tests are conducted with the involvement of representatives of the State Research Institute 
of the Ministry of Internal Affairs of Ukraine, the Canine Department of the National Police and the Institute of Organic Chemistry of the NAS of Ukraine in July-November 2017 and in October 2019, with the results of preliminary and acceptance tests documented 15-19].

\section{PSEUDO COCAINE SCENTS}

The analysis of the academic literature on the composition and principle of action of pseudo narcotic scents has shown that the smell inherent in narcotic drug belongs to volatile impurities that are either products of narcotic substance decomposition, or by-products formed during its synthesis, rather than to the drug itself (that usually is odorless) [4, 6-9].

Thus, it has been found that the smell of cocaine is caused by the two substances: methyl benzoate (methyl ester of benzoic acid) and methyl cinnamate (methyl ester of cinnamic acid), which are decomposition products of coca alkaloids and get into the sample while extracting cocaine from natural raw materials $[6,9]$. There are data that "street" cocaine samples may content benzoic acid [9].

Sigma uses only one of these substances, methyl benzoate, for producing pseudo cocaine scent [6]. The ScentLogix product contains the other substance, methyl cinnamate, in a high concentration, as an odorological substance and benzoic acid [10]. Below, the chemical composition of foreign-made pseudo cocaine scent is given:

- Sigma Pseudo Narcotic Scent Cocaine [6]: microcrystalline cellulose $(98.9 \%)$, silica gel (1\%), and methyl benzoate $(0.1 \%)$;

- ScentLogix pseudo cocaine scent [10]: 2 g methyl cinnamate, $2 \mathrm{~g}$ benzoic acid, $10 \mathrm{~g}$ diatomaceous earth.

Different groups of researchers have received conflicting data on which component determines the smell of "street" cocaine [3]. According to some studies, more volatile component, methyl benzoate, dominates in cocaine $[3,9]$. The other authors point out that service dogs have found samples of cocaine in which the concentration
Table 1. Tests of Pseudo Cocaine Scent Samples

\begin{tabular}{|c|c|c|c|}
\hline \multirow{2}{*}{ Formulation } & \multicolumn{3}{|c|}{ CDegree of interest of service dog while searching* } \\
\cline { 2 - 4 } & "no reaction" & "interest" & "clear detection" \\
\hline C-1 & 1 & - & - \\
C-2 & - & - & $3,4,6,7,8,9,10$ \\
C-3 & 1 & - & - \\
\hline
\end{tabular}

Note. Hereinafter, ${ }^{*}$ the number corresponds to the counting number of dog (see Section Testing of Designed Formulations on Service Dogs).

of methyl benzoate is below the threshold sensitivity [3].

Therefore, for more accurate simulation of cocaine smell, both components, methyl benzoate and methyl cinnamate, are used. Two formulations C-1 and $\mathrm{C}-2$, which differ in the proportion of active components have been prepared. In addition, there has been designed the $\mathrm{C}-3$ formulation that has a composition similar to the pseudo cocaine scent manufactured by ScentLogix, but contains a lower concentration of odorological substance, in order to make the formulation suitable for training dogs to search for small amounts of drugs.

The tests have shown that the most effective formulation is C-2, while other ones are not found by dogs trained to search for cocaine with the use of both foreign-made products and authentic drug. The test results are given in Table 1.

\section{PSEUDO HEROIN SCENTS}

The studies have shown that heroin is characterized by the smell of acetic acid that remains in drug samples after acylation of morphine with acetic anhydride and is formed as a result of gradual hydrolysis of the heroin itself by moist air [6].

That is why the pseudo scent manufactured by Sigma contains acetic acid, while that made by ScentLogix has a compound that emits acetic acid as a result of its hydrolysis by moist air:

- Sigma Pseudo Narcotic Scent Heroin [6]: ]: microcrystalline cellulose (74.1\%), acetylsalicylic acid (25.2\%), acetic acid (0.3\%), silica gel (0.3\%);

- ScentLogix [10]: pseudo heroin scent [10]: $4 \mathrm{~g}$ phenyl acetate, $10 \mathrm{~g}$ diatomaceous earth. 
The unlike the commercial mimics, the formulations $\mathrm{H}-1$ and $\mathrm{H}-2$ do not contain acetic acid, but have a compound that decomposes in the presence of water with the formation of acetic acid (o-acetylsalicylic acid) and a catalyst of this process (4-toluenesulfonic acid monohydrate). The $\mathrm{H}-1$ formulation contains water. The H-2 formulation does not contain water (except for that bound with 4-toluenesulfonic acid), and the catalyst concentration is reduced in order to slow down the rate of hydrolysis of acetylsalicylic acid and to extend the shelf life of the formulation.

The H-3 formulation that contains only o-acetylsalicylic acid and an inert carrier is designed and tested to exclude that dogs react to o-acetylsalicylic acid having a slight specific odor, insofar they have to react only on the product of its hydrolysis, acetic acid.

The tests have shown that both formulations, $\mathrm{H}-1$ and $\mathrm{H}-2$, are effective. Some dogs show a little interest in the $\mathrm{H}-3$ formulation. The test results are given in Table 2 .

\section{PSEUDO}

\section{AMPHETAMINE SCENTS}

Amphetamine and methamphetamine are usually synthesized in illegal laboratories by one of the three methods: from benzyl methylamine, phenyl acetone or ephedrine derivatives. In all cases, benzaldehyde is formed as a by-product of the reaction. In addition, phenyl acetone is present in all samples of amphetamines (in one method of synthesis, it is a precursor, in others it is a byproduct). These two substances, phenyl acetone and benzaldehyde, odorize the drug samples [10]. Based on them, the ScentLogix commercial pseudo scent is designed [10]:

Table 2. Tests of Pseudo Heroin Scent Samples

\begin{tabular}{|c|c|c|c|}
\hline \multirow{2}{*}{ Formulation } & \multicolumn{3}{|c|}{ Degree of interest of service dog while searching * } \\
\cline { 2 - 4 } & "no reaction" & "interest" & "clear detection" \\
\hline H-1 & - & - & 1,4 \\
H-2 & - & 8 & $3,4,6,7,9,12$ \\
H-3 & - & 1 & - \\
\hline
\end{tabular}

ISSN 2409-9066. Sci. innov. 2020. $16(5)$
- Pseudo methamphetamine scent: $1.5 \mathrm{~g}$ benzaldehyde, $2 \mathrm{~g}$ propiophenone, $10 \mathrm{~g}$ microcrystalline cellulose.

The Met-1 formulation has the components of which and their ratio identical to the commercial ScentLogix pseudo scent, but the concentration of components is 30 times lower, as the latter has a very strong concentrated scent. In our opinion, the dogs trained on a formulation with such an intense scent may detect only large batches of methamphetamine and fail to react on small doses of the narcotic drug, which is unacceptable.

Since benzaldehyde is easily oxidized to benzoic asid by oxygen, which may lead to the loss of its odorological properties in the case of regular use, benzaldehyde has been replaced by a substance that releases it gradually. So, the Met-2 formulation has been designed. It contains 2-phenyl-1,3-dioxan-5-ol that upon hydrolysis by 4toluenesulfonic acid monohydrate is converted into benzaldehyde and gives the mixture odorological properties identical to the authentic amphetamine samples. In this case, the main active ingredient is formed gradually and is always present in the formulation. As a result of hydrolysis, glycerol is also formed. It is non-toxic, has no specific odor, and does not affect the pseudo scent properties.

The tests have shown that both formulations Met-1 and Met-2 are effective. The test results are given in Table 3 .

\section{PSEUDO MARIJUANA SCENTS}

The marijuana smell of is caused by the presence of various terpene compounds, including $\beta$-caryophyllene, limonene, myrcene, $\gamma$-terpinene, $\alpha-, \beta$ and $\gamma$-pinene, etc. in the hemp leaves $[6,8]$.

Table 3. Tests of Pseudo Amphetamine Scent Samples

\begin{tabular}{|c|c|c|c|}
\hline \multirow{2}{*}{ Formulation } & \multicolumn{3}{|c|}{ Degree of interest of service dog while searching * } \\
\cline { 2 - 4 } & "no reaction" & "interest" & "clear detection" \\
\hline Met-1 & - & 3 & $1,2,4,6,7,8,9,10$ \\
Met-2 & - & - & $2,8,9$ \\
\hline
\end{tabular}


Table 4. Tests of Pseudo Cannabis Scent Samples

\begin{tabular}{|c|c|c|c|}
\hline \multirow{2}{*}{ Formulation } & \multicolumn{3}{|c|}{ Degree of interest of service dog while searching* } \\
\cline { 2 - 4 } & "no reaction" & "interest" & "clear detection" \\
\hline Mar-1 & - & 8 & 2,9 \\
\hline
\end{tabular}

There are several pseudo cannabis scents used for training and certification of service dogs, for example:

- Sigma Pseudo Narcotic Scent Marijuana [6]: microcrystalline cellulose $(98.5 \%)$, silica gel $(1 \%)$, butane-2,3-diol (0.4\%), and $\gamma$-terpinene $(0.1 \%)$;

- ScentLogix pseudo marijuana scent [10]: $2.2 \mathrm{~g}$ $\beta$-caryophyllene, $3.65 \mathrm{~g}$ myrcene, and $20 \mathrm{~g}$ microcrystalline cellulose.

At the same time, the above formulations have significant disadvantages. They contain, at most, two odor components, although there are, at least, 200 substances that determine its smell. In the case of dog training, it is more appropriate to use multicomponent formulations containing natural compounds that are present in the green part of hemp.

The Mar-1 formulation containing $\alpha$-pinene, $\beta$-pinene, $\gamma$-terpinene, 2 ,3-butanediol, vitamin E, and hemp oil has been designed. Its composition contains the main components of evaporation from dried hemp leaves, as well as vitamin E, an antioxidant that has no specific odor and prevents spoilage of the formulation by air oxidation of active odorous components. Hemp oil improves the odorological properties of the formulation and brings its smell closer to that of genuine hemp.

The tests have shown that the Mar-1 formulation is effective. The test results are given in Table 4.

\section{PSEUDO SCENTS OF CRUDE OPIUM}

No reliable data on the odorological properties of opium have been found in the literature. In [11], it is noted that the odor characteristic of crude opium is determined by more than 70 components, and that a blend of 2-methylpyrazine (0.5\%), 2,5-dimethylpyrazine (0.01\%), 2,6-dimethylpyrazine $(0.1 \%)$, 2-methoxy-3-isopropylpyrazine $(0.001 \%)$, 2-methoxy-3-isobutylpyrazine $(0.001 \%)$ and an inert carrier creates a smell that
Table 5. Tests of Crude Opium Pseudo Scent Samples

\begin{tabular}{|c|c|c|c|}
\hline \multirow{2}{*}{ Formulation } & \multicolumn{3}{|c|}{ Degree of interest of service dog while searching* } \\
\cline { 2 - 4 } & "no reaction" & "interest" & "clear detection" \\
\hline O-1 & - & 3 & 11 \\
O-2 & 11 & - & - \\
O-3 & 11 & - & 3,10 \\
\hline
\end{tabular}

perfumers and trained service dogs perceive as a scent of opium.

Since there are no commercial pseudo scents of opium, and the components of the opium smell is described in only one research [11], the O-1 formulation has been designed based on the data specified in the literature.

Given the authors' data on volatile substances found in the headspace of opium, the O-2 and O-3 as modifications of the $\mathrm{O}-1$ have been designed. O-2 contains components whose concentration in the headspace of opium is more than $1 \%$, in particular aliphatic aldehydes with a chain length of C6-C10. O-3 has the same components as O-1, but in a different proportion and with a higher concentration.

The tests have shown that the $\mathrm{O}-3$ formulation is the most effective. The test results are given in Table 5.

\section{PSEUDO SCENTS OF POPPY STRAW}

Given the geographical location of our country, the problem of distribution and use of poppy straw is very relevant, however, there are have been no commercial pseudo scents of poppy straw, and its odorological profile has not been studied.

In our region, there is a plant from the poppy family, celandine (Chelidonium majus L.). The affinity of these plants implies the similarity of metabolic ways and metabolic products present in the green part of the plants. In particular, they

Table 6. Tests of Poppy Straw Pseudo Scent Samples

\begin{tabular}{|c|c|c|c|}
\hline \multirow{2}{*}{ Formulation } & \multicolumn{3}{|c|}{ Degree of interest of service dog while searching* } \\
\cline { 2 - 4 } & "no reaction" & "interest" & "clear detection" \\
\hline M-1 & 7 & - & $3,4,8,9,11$ \\
\hline
\end{tabular}


contain a similar set of alkaloids and terpene compounds [12-14]. Based on the assumption that the dried celandine straw has a smell similar to that of poppy straw, the M-1 formulation has been designed. It consists of dried celandine straw and an inert carrier.

The tests have shown that five out of six dogs react on the pseudo scent. The test results are given in Table 6.

Thus, domestic pseudo narcotic scents of cocaine, heroin, marijuana, methamphetamine, crude opium, and poppy straw, which do not have narcotic effect, but possess the same odorological profile as the authentic drug samples have been designed. It should be noted that the pseudo scents of crude opium and poppy straw have no counterparts in the world and are not commercially available today.

Based on the results of tests involving specially trained service dogs of canine units, there have been identified the formulations that are promising for commercialization and further use for training activities of canine units of the Ministry of Internal Affairs of Ukraine in terms of setting service dogs on smell of authentic drugs.

Pilot formulations of pseudo narcotic scents (cocaine, heroin, marijuana, methamphetamine, crude opium, and poppy straw) have been manufactured and transferred for experimental use to the Canine Service of the National Police of Ukraine.

\section{REFERENCES}

1. On approval of the Instruction on the organization of the activities of the cynological subdivisions of the National Police of Ukraine: The order of the Ministry of Internal Affairs of Ukraine from 01.11.2016 No. 1145 [in Ukrainian].

2. On Approval of the List of Narcotic Drugs, Psychotropic Substances and Precursors: Resolution of the Cabinet of Ministers of Ukraine dated May 6, 2000 No. 770. Official Bulletin of Ukraine (2000), No. 19, 789 [in Ukrainian].

3. Jezierski, T., Ensminger, J., Papet, L.E. (Eds.) (2016). Canine Olfaction Science and Laze. Advances in Forensic Science, Medicine, Conservation, and Environmental Remediation. Boca Raton: CRC Press.

4. Inoue, H., Iwata, Y. T., Kuwayama, K. (2008). Characterization and Profiling of Methamphetamine Seizures. J. Health Sci., 54(6), 615-622. https://doi.org/10.1248/jhs.54.615.

5. Kostyk, I. F., Kapustnyk, V. A. (2003). Occupational illness: textbook. Kyiv: Zdorov'ya. P. 52-79 [in Ukrainian].

6. Rice, S., Koziel, J. A. (2015). Odor impact of volatiles emitted from marijuana, cocaine, heroin and their surrogate scents. Data in Brief., 5, 653-706. doi:10.1016/j.dib.2015.09.053.

7. Rice, S., Koziel, J. A. (2015). The relationship between chemical concentration and odor activity value explains the inconsistency in making a comprehensive surrogate scent training tool representative of illicit drugs. Forensic Science International, 257, 257-270. https://doi.org/10.1016/j.forsciint.2015.08.027.

8. Rice, S., Koziel, J. A. (2015). Characterizing the Smell of Marijuana by Odor Impact of Volatile Compounds. In: Application of Simultaneous Chemical and Sensory Analysis. PLoS ONE, 10(12), e0144160. https://doi.org/10.1371/journal. pone. 0144160 .

9. US Patent № 4260517. Woodford, W. J. Available aroma of cocaine.

10. US Patent № 2014/0311218 A1. Adebimpe D. Methods of producing pseudoscent compositions of narcotic materials and compositions thereof.

11. Buchbauer, G., Buchbauer, G., Nikiforov, A., Remberg, B. (1994). Headspace constituents of opium. Planta Med., 60, 181-183. doi: 10.1055/s-2006-959447.

12. Desgagné-Penix, I., Khan, M. F., Schriemer, D. C., Nowak, J., Facchini, P. J. (2010). Integration of deep transcriptome and proteome analyses reveals the components of alkaloid metabolism in opium poppy cell cultures. BMC Plant Biology, 10, 252. https://doi.org/10.1186/1471-2229-10-252.

13. Hao, Da, Xiao, Jie, Gu, Pei, Gen Xiao (2015). Chapter 5: Phytochemical and biological research of Chelidonieae pharmaceutical resources. In: Medical Plants. Elsevier. 171-216. https://doi.org/10.1016/B978-0-08-100085-4.00005-0.

14. Manske, R. H. F. (1968). Chapter 8: Papaveraceae Alkaloids. In: The Alkaloids: Chemistry and Physiology. Elsevier. 10, 467-483. https://doi.org/10.1016/S1876-0813(08)60260-2.

15. Protocols of preliminary testing of experimental samples of odor requisites (simulators) of narcotic substances from 28.07.2017.

16. Protocol of preliminary testing of experimental samples of odor requisites (simulators) of narcotic substances from 22.08.2017. 
17. Protocol of testing of experimental samples of odor requisites (simulators) of narcotic substances from 11.12.2017.

18. Protocol of preliminary testing of experimental samples of odor requisites (simulators) of narcotic substances from 17.10.2019.

19. Protocol of testing of experimental samples of odor requisites (simulators) of narcotic substances from 25.10.2019.

Received 28.10.19

Revised 17.12.19

Accepted 17.02.20

Л.В. Соколенко ${ }^{1}$, Т.М. Соколенко ${ }^{1}$, Ю.Л. Ягупольський ${ }^{1}$,

В.І. Кальченко ${ }^{1}$ Ю.В. Вересенко ${ }^{2}$, О.В. Неня², Ю.Д. Кучинський ${ }^{2}$,

Д.В. Смерницький ${ }^{2}$ О.В. Скоробагатько ${ }^{2}$,

М.А. Скоробагатько ${ }^{3}$, С.І. Коломієиь ${ }^{3}$

${ }^{1}$ Інститут органічної хімії НАН України, вул. Мурманська, 5, Київ, 02660, Україна, +380 44559 0349, +380 44573 2643, ioch@ioch.kiev.ua

2 Державний науково-дослідний інститут МВС України, пров. Євгена Гуцала, 4-а, Київ, 01011, Україна,

+380 44280 0184, dndi@mvs.gov.ua

${ }^{3}$ Відділ організації кінологічної діяльності Національної поліції України, вул. Богомольця, 10, Київ, 01601, Україна,

+380 44254 7735, kinologs1@police.gov.ua

\section{IМІТАТОРИ ЗАПАХУ НАРКОТИЧНИХ}

ЗАСОБІВ ДЛЯ ДРЕСИРУВАННЯ

СЛУЖБОВИХ СОБАК: СКЛАД, ПРИНЦИП ДІЇ

ТА ПРАВОВА ОСНОВА ВИКОРИСТАННЯ

Вступ. Залучення кінологічних підрозділів до виявлення наркотичних засобів активно застосовують завдяки високій чутливості нюху собак.

Проблематика. Для дресирування та тренування службових собак кінологічним підрозділам органів системи МВС України дозволено використовувати зразки справжніх наркотичних засобів (НЗ) з метою вироблення або підтримання відповідного навику у тварини. Проте НЗ є підконтрольними речовинами, тому існує особливий нормативно-правовий порядок їхнього застосування, що значно ускладнює процедуру підготовки тварин.

Використання НЗ є доцільним під час базової підготовки собак у спеціальних кінологічних школах. Подальше тренування, спрямоване на підтримання навиків, яке здійснюється безпосередньо у кінологічних підрозділах, проводиться з використанням запахових замінників, які не містять у своєму складі НЗ, отже не є наркотично активними. Переважна більшість останніх є імпортними та високовартісними, що не дає змоги забезпечити всі потреби відповідних служб. Крім того, існуючі замінники мають обмежений асортимент.

Мета роботи. Розробка вітчизняних імітаторів запаху НЗ, які б не були наркотично активними, проте мали ідентичні одорологічні властивості, а їхня вартість була значно нижчою закордонних аналогів, розширення асортименту імітаторів НЗ.

Матеріали й методи. Для створення запахових замінників кокаїну, героїну, марихуани, метамфетаміну, опіюсирцю та макової соломки було використано інертний носій та леткі домішки, що містяться в зазначених НЗ. Випробування розробок здійснювали із залученням 12-ти службових собак кінологічних підрозділів Національної поліції України та Держприкордонслужби України.

Результати. Створено суміші-імітатори запаху найбільш поширених НЗ, які випробувано в роботі з собаками і показано відповідність їхнього одорологічного профілю оригінальним НЗ.

Висновки. Визначено суміші, які є перспективними для впровадження у виробництво та подальшого використання під час навчально-тренувальної діяльності кінологічних підрозділів.

Ключові слова: імітатори запаху наркотичних засобів, кокаїн, героїн, марихуана, метамфетамін, опій-сирець, макова соломка. 